\title{
Winston Peters "Puts His Hand to the Plow": The Bible in New Zealand Political Discourse
}

DOI 10.1515/jbr-2016-1010

Abstract: This article examines the charismatic New Zealand politician Winston Peters' sparse use of the Bible as a case study in the propagation of the "Cultural" and "Liberal" Bibles across the relatively irreligious landscape of New Zealand's political landscape. It considers why politicians continue to employ biblical rhetoric despite increasing indifference towards Christianity and the Bible, by situating such moves within the context of global capitalism. It also identifies some peculiarities of the political use of the Bible unique to the New Zealand situation and explores how these have aided the construction of distinctive political identities.

"Jesus said to him, 'No one who puts a hand to the plow and looks back is fit for the Kingdom of God'.” - Luke 9:62

“The Old Testament was my textbook.” - Winston Peters

Keywords: New Zealand; cultural Bible; Bible and politics; Winston Peters; capitalism; Luke 9:62.

\section{Introduction}

On the eve of a by-election to replace an outgoing Member of Parliament in early 2015, the charismatic New Zealand politician Winston Peters appeared on the televised news and confidently declared that his campaign to win the Northland electorate could be compared to a man who puts his hand to the plow and has the determination to not look backwards. It was a reference to something Jesus says in Luke 9:62. Peters went on to win the by-election by a sizeable majority. What was surprising about this brief moment of biblical oration was that it has

\footnotetext{
*Corresponding author: Robert J. Myles, Theological and Religious Studies, School of Humanities, University of Auckland, New Zealand, e-mail: r.myles@auckland.ac.nz
} 
otherwise become an exceedingly rare occurrence within parliamentary politics in New Zealand for the Bible to be mentioned at all, let alone to feature on the prime-time news. Political discourse in New Zealand is, for the most part, decidedly secular. By secular I do not mean "anti-religious", but rather the belief is upheld that no (one) religion should be afforded special privileges. A secondary feature of secularism, one that often creeps into the popular consciousness, is the idea of the separation of church and state; in other words, the state, morals, and education should function independently of religious influence. ${ }^{1}$ With a couple of exceptions, most notably an assortment of fringe Christian parties that have thus far failed to gain representation in parliament, ${ }^{2}$ religion rarely infiltrates political discourse in the way it might in other Western democracies, most notably the United States. ${ }^{3}$

Demographics of the voting population partially explain why this is the case. While New Zealand has no "official" religion, ${ }^{4}$ and Christianity has remained

1 Roland Boer, "Introduction," in Secularism and Biblical Studies, ed. Roland Boer, BibleWorld (London: Equinox, 2010): 1-5.

2 Despite gaining media exposure, the political entities of the (now defunct) Destiny Party and the Conservative Party of New Zealand have not as of yet gained entry. One exception is United Future which was formed by the merger of United New Zealand and a Christian-dominated Future New Zealand which had previously contested the 1996 general election as part of the Christian Coalition. United Future's entry to parliament in 2002, however, was made possible by its abandonment of any explicit religious connection. Shortly before it was elected, its party president Inky Tulloch remarked that “United Future isn't a Christian party - it's a political party that has a lot of Christians in it, and a lot of non-Christians." Hannah Tunnah, "Art of Compromise at Coalition Party Conference," NZ Herald, March 11, 2003, accessed May 1, 2015, http://www. nzherald.co.nz/nz/news/article.cfm?c_id=1\&objectid=3532099.

3 Whereas US Presidents George W. Bush and Barack Obama, UK Prime Ministers Tony Blair and David Cameron, and Australian Prime Ministers John Howard, Kevin Rudd and Tony Abbott have all at some point championed their personal religious beliefs as driving forces behind their respective political ambitions and/or party policy, such explicit declarations are almost unheard of among successful New Zealand politicians. The current Prime Minister John Key said in 2006 that although he occasionally attends church he does not believe in life after death and generally sees religion as “doing the right thing." Key's precursor, Helen Clark, likewise claimed to be an agnostic. Even New Zealand's close geographical and cultural neighbour, Australia, has witnessed a remarkably different history of parliamentary politics intersecting with religion. See, for example: Marion Maddox, God Under Howard: The Rise of the Religious Right in Australian Politics (Crows Nest, NSW: Allen \& Unwin, 2005).

4 While legally speaking there is no official religion in New Zealand, the role Christianity has played historically means that some traditions and conventions remain. For example, a traditional prayer is read before the opening of each session in Parliament. Furthermore, the national anthem invokes God to defend the country, and various Christian holidays are recognized as official holidays. The Anglican church in New Zealand is constituted by the Church of England empowering act. 
the majority religious affiliation since European settlement in the nineteenth century, its influence has waned considerably in recent decades. The population is now marked by a rapidly growing indifference to institutional religion. By the 2013 national Census, the proportion of those who indicated they had no religion had risen to $41.9 \%$. For the first time, the proportion affiliated with a Christian religion registered below 50\%, and, of course, this number includes what might be called the "nominally affiliated" who identify with Christianity in a vague or loose sense. ${ }^{5}$ Given this increased indifference to religion, it is not surprising that politicians would generally want to avoid the Bible and/or religion altogether. The risk of alienating a large proportion of the population is just too great. Even so, the Bible occasionally resurfaces both implicitly and explicitly in political discourse. The relative infrequency of these occurrences provides the perfect opportunity for a detailed examination of how the Bible functions in a context outside of its more familiar environment of institutionalized religion.

Accordingly, this article draws on Peters' sparse use of the Bible as a case study in the propagation of the "Cultural Bible" across the relatively irreligious landscape of New Zealand political culture. The Cultural Bible refers to the use of the Bible beyond its typical confines of institutional religion. The article will consider the iconic and rhetorical function of Peters' occasional references to the Bible, and repeated claims to knowledge of ancient Hebrew, but also takes a broader account of the presence (or absence) of the Bible in the construction of a particular political identity. It examines what makes infrequent references to the Bible palatable within a highly secularized political context that is generally suspicious of, and in some cases overtly hostile to, the incursion of religious influence. It also pushes a further point, namely, that every use of the Bible in contemporary political discourse is also, at one and the same time, an implicit or explicit political stance on the nature of multinational capitalism today. If we take the Marxist idea that class struggle is the motor force of history, then the Cultural Bible should be located within the ideological superstructure and analyzed with respect to the economic base upon which it is ultimately dependent. Because the emergence of the Cultural Bible is aligned historically to the rise and development of capitalism, and the dominant ideas of an age are the ideas of the ruling class, an appeal to the Bible's presumed cultural authority is simultaneously the deployment of a specific bourgeois creation. As we will observe, Peters' Bible is allied to an older style of capitalism, which emphasizes the protection

5 “Census QuickStats about Culture and Identity," Statistics New Zealand: Tatauranga Aotearoa, April 15, 2014, accessed May 1, 2015, http://www.stats.govt.nz/Census/2013-census/profile-andsummary-reports/quickstats-culture-identity/religion.aspx. 
of national economic interests, promotes a liberal conception of tolerance, and upholds the capitalist myth that hard work and determination will be rewarded with individual success.

Before getting to an examination of Peters' Bible in particular, I want to first introduce some previous research that will aid us in situating the various guises the Bible can take in contemporary political discourse. Because existing literature on the Bible and politics has been developed with regard to other contexts (primarily the US and England) I make a concerted effort to adapt one recent theory to the distinctive idiosyncrasies of the New Zealand political and cultural landscape. The implication of the Bible in political discourse should not, of course, be confined to the parochial circles of US and British politics. The treatment of what may seem, to an international audience, like an obscure topic, should illustrate how themes that have been addressed elsewhere apply in a particular and distinct way to this case in New Zealand.

\section{The Bible in Contemporary Political Discourse}

As is hopefully obvious by now, the function of the Bible as an icon of cultural power is by no means confined to the inside of religious communities. As Yvonne Sherwood remarks, "the Bible-in-general or the Bible-as-icon functions as an overwhelming religious-cultural-political sensation, a sense of colour and form that has little to do with the text." ${ }^{6}$ Similarly, according to Erin Runions, repeated appeals to biblical authority in the US, often in the guise of popularized and occasionally secularized modes of Protestant interpretation, "smooth the way for the continual attempts to reassert US power in a world where national sovereignty must bow before the transnational circuits of capital and power."

In his recent monograph, Harnessing Chaos: The Bible in English Political Discourse Since 1968, James G. Crossley, building on the work of Sherwood, presents an extremely useful taxonomy of the use of the Bible in politics that divides into roughly four categories: the Cultural Bible; the Liberal Bible; the Neoliberal Bible; and the Radical Bible. ${ }^{8}$ What I take most strongly from Crossley's book is

6 Yvonne Sherwood, Biblical Blaspheming: Trials of the Sacred for a Secular Age (Cambridge: Cambridge University Press, 2012), 2.

7 Erin Runions, The Babylon Complex: Theopolitical Fantasies of War, Sex, and Sovereignty (New York: Fordham University Press, 2014), 1-2.

8 James G. Crossley, Harnessing Chaos: The Bible in English Political Discourse Since 1968, Scriptural Traces (London: Bloomsbury, 2014). 
that, rather than the Bible explicitly or implicitly influencing the direction of parliamentary politics per se, it functions primarily to buttress politicians' existing agendas. The actual content of the Bible matters very little and can just as easily be used to justify radical opposition (for example, the Occupy movement) as it can to establish the importance of personal responsibility or individualism (for example, Thatcherism) as the cornerstones of a purported English identity. What seems to matter most about the Bible, despite its general loss of religious significance, is its traditional and cultural appeal.

A product of the European Enlightenment, the "Cultural Bible," according to Sherwood and Crossley, describes the use of the Bible as a philological and pedagogical resource, a literary classic, a moral guidebook, and a historical archive. While the metaphysical and supernatural claims made by the text are implicitly bracketed to one side, the Bible is still championed as underpinning certain aspects of our shared cultural heritage and identity. The Cultural Bible repeatedly surfaces within New Zealand political discourse where an implicit code governing acceptable forms of biblically-inspired rhetoric rests on a dichotomized view of religion. Crudely put, it is generally deemed acceptable for politicians to speak of religion in a broadly moral and/or traditional sense. However, explicitly invoking God and/or speaking of religion or the Bible in a supernatural or metaphysical sense can quickly lead to trouble.

Pushing the Cultural Bible further, the "Liberal Bible" refers to the idea that what the Bible is "really about" is a prototype of liberal values like freedom, democracy, and individual human rights. Sherwood describes the Liberal Bible as "the vague modern chimera of Bible where the Bible conveniently and usefully becomes a vague container for morality (the religious translated into practical, universal and utilitarian terms), the civil, the democratic and the humane." Domenico Losurdo has demonstrated how the various contradictions within the most important developments of liberal thought took place alongside the rise of capitalism and against the backdrop of widespread slavery.$^{10}$ It is worth including within this category, then, the typically understated view that the Liberal Bible is also used to espouse the tenets of liberalism's economic handmaiden, capitalism. This includes using the Bible to naturalize the interests of private property, individual entrepreneurship, and other values upheld by the bourgeoisie (the ruling class under the capitalist social formation). For example, the Liberal Bible has repeatedly been mobilized in parliamentary politics to sacralize dominant concepts of labor exploitation. During the Leaders' Debate between the National

9 Sherwood, Biblical Blaspheming, 4.

10 Domenico Losurdo, Liberalism: A Counter-History, trans. Gregory Elliott (London: Verso, 2011). 
Party leader Robert Muldoon and the Labour Party leader David Lange for the 1984 general election, for instance, biblical language was repeatedly evoked. Muldoon suggested that the people of New Zealand should distrust the "Socialist trade union party that promises them the kingdom of God without prayer and the goods of this Earth without work." ${ }^{11}$ Presumably this was meant to align the values of the Bible to capitalist ideology.

However, just as the Bible has been used to rationalize the supposed "timelessness" of Western liberal and capitalist values, it has equally been used to underwrite a plethora of competing worldviews and value systems. The Liberal Bible, in fact, represents a shift from the Monarchist's Bible, under which the Monarch's authority and the feudalist social formation was sustained by claims to divine sanction. Similarly, the "Neoliberal Bible," as suggested by Crossley, represents the idea that the Bible is largely compatible with the ideals of neoliberal governance which has gradually embedded itself as the dominant political ideology in the West over the past forty or so years. Neoliberalism refers to the contemporary, "post-political" milieu in which politics is treated primarily as economic administration and management in contrast to representing the class interests of particular groups in society. An intensification of classical liberal ideals, it promotes cultural indeterminacy, individualism, the free market, deregulation, and the privatization of welfare and other aspects of the state. ${ }^{12}$

While neoliberal ideology functions as a "hegemonic mode of discourse"13 in New Zealand, the Neoliberal Bible has itself been relatively absent from political discourse. This is in stark contrast to England and the US. It appears that politicians in New Zealand have seen less reason to justify moves towards multiculturalism, unbridled markets, and privatization through biblical validation. Interestingly, Winston Peters' has typically positioned himself against certain tenets of neoliberal ideology, for instance, by opposing privatization and advocating the safeguard of certain nationalist interests. Be that as it may, he is by no means opposed to capitalist ideology as such; rather his political orientation is largely affixed to an older style of capitalism at odds with the new neoliberal orthodoxy.

Finally, the "Radical Bible" is an alternative tradition to the Liberal, and Neoliberal Bibles which equates the Bible with the legacy of Socialist politics

11 “The 1984 Leaders’ Debate,” NZ on Screen, accessed May 1, 2015, http://www.nzonscreen. com/title/the-1984-leaders-debate-1984.

12 For more on the influence of neoliberal ideology on biblical scholarship, see: James G. Crossley, Jesus in an Age of Neoliberalism: Quests, Scholarship, and Ideology (Sheffield: Equinox, 2012); Robert J. Myles, The Homeless Jesus in the Gospel of Matthew (Sheffield: Sheffield Phoenix, 2014). 13 David Harvey, A Brief History of Neoliberalism (Oxford: Oxford University Press, 2005$), 3$. 
and other radical and revolutionary movements. Like the Liberal and Neoliberal Bibles, the Radical Bible still rests on claims to what the text "really means." It wields the cultural power of the Bible to ground a critical posture towards unbridled capitalism and abuses of political power. Crossley suggests that the Radical Bible was effectively pushed to the fringes of English parliamentary politics altogether during the rise and consolidation of Thatcherism and the decline of Keynesian economics. ${ }^{14}$ This is also apparent in New Zealand, where a soft version of the Radical Bible once existed at the center of the political establishment but now remains firmly on its margins, if it is to be found at all. In 1938 the then Labour Prime Minister Michael Joseph Savage began drawing up plans for the welfare state, famously terming it "Applied Christianity." Savage regarded the implementation of a social safety net as a deliberate outworking of his Roman Catholic faith - it was the "kingdom of heaven" come to Earth - and he frequently employed biblical themes and imagery to bolster his political rhetoric. In subsequent decades, however, the Radical Bible once espoused by Savage became less viable for mainstream politics, and this tradition has largely disappeared from purview.

Even so, an alternative Radical Bible generated by New Zealand's distinct colonial heritage continues to have a presence in current-day political discourse. This alternative tradition draws less on Socialist influences and more on radical indigenous responses to European colonialism. Specifically, the colonial encounter of British settlers and missionaries in the nineteenth century gave rise to a particular reading of the Bible amongst some Māori who responded by privileging aspects of the Old Testament over the New. Indeed, by the time of the signing of New Zealand's founding document the Treaty of Waitangi in $1840,{ }^{15}$ Māori had begun to regard themselves in a position similar to that of the ancient Israelites under foreign rule in their own land. As a result, a number of Māori religious movements emphasized their supposedly "Hebraic" elements. As Judith E. McKinlay notes, "Māori biblicism moved on to become markedly different from that taught by the missionaries. Māori prophetic movements multiplied as biblically literate leaders found in the scriptures a framework for ordering their lives

14 Crossley, Harnessing Chaos, 10-19.

15 The treaty was meant to be a partnership between Māori and the British Crown. While supposed to create unity, different interpretations and breaches of its clauses have caused conflict. Since the 1970s increased efforts by the government and other stakeholders have been made to honour the principles of the treaty. See further: Allan K. Davidson, "The Interaction of Missionary and Colonial Christianity in Nineteenth Century New Zealand," Studies in World Christianity 2 (1996), 145-66. 
both under and against the colonizers.” 16 This took place not necessarily as a rejection of Christianity, but rather as one aspect of the syncretization of the new missionary teachings from Pākehā (those of European descent) with the beliefs and situation of the colonized Māori. ${ }^{17}$

This alternative Radical Bible still occasionally manifests in current-day political discourse. One such example involves the leader of the Mana Party, Hone Harawira, whose core constituency of mostly northern Māori has a relatively high concentration of religious adherence. The Left-wing Mana Party was formed in 2011 following Harawira's resignation from the Māori Party, which was in coalition with the governing centre-Right National Party. Mana described its mission as giving voice to "the poor, the powerless and the dispossessed" and striving to "empower them against the government by the rich and powerful for the rich and powerful." ${ }^{18}$ Harawira himself has claimed to draw inspiration from traditional Māori spirituality and not Christianity. ${ }^{19}$ However, in the lead up to the $2011 \mathrm{Te}$ Tai Tokerau (a reserved parliamentary seat for the representation of Māori) byelection, members of the prominent Ratana church asserted that Harawira was the fulfillment of a prophecy. Ratana is both a form of Māori Christianity and an indigenous political movement founded in the early twentieth century. ${ }^{20}$ Its founder, Tahupotiki Wiremu Ratana (1873-1939), is reported to have uttered: “[t] urn your eyes to the north, a young man will rise up carrying the Treaty [of Waitangi]." A senior minister from the church in 2011 explained that "[t]he founder of

16 Judith E. McKinlay, "Braiding the Traditions in Aotearoa/New Zealand," in The Future of the Biblical Past: Envisioning Biblical Studies on a Global Key, eds. Roland Boer and Fernando F. Segovia (Atlanta: SBL, 2012): 209. Cf. Judith E. Mckinley, Troubling Women and Land: Reading Biblical Texts in Aotearoa New Zealand. Bible in the Modern World 59 (Sheffield: Sheffield Phoenix, 2014); Homi K. Bhabha, The Location of Culture (London: Routledge, 1994).

17 See further: Bronwyn Elsmore, Like Them That Dream: The Māori and the Old Testament, 3rd edn. (Auckland: Libro International, 2011); David M. Gunn, "Colonialism and the Vagaries of Scripture: Te Kooti in Canaan (A Story of Bible and Dispossession in Aotearoa/New Zealand)," in God in the Fray, eds. Tod Linafelt and Timothy K. Beal (Minneapolis: Fortress, 1998): 127-142; Mary Huie-Jolly, "Māori 'Jews' and a Resistant Reading of John 5.10-47," in John and Postcolonialism: Travel, Space and Power, eds. Musa W. Dube and Jeffrey L. Staley (London: Sheffield Academic, 2002): 94-110; Bronwyn Elsmore, “The 'Jews' Response” in Mana From Heaven: A Century of Māori Prophets in New Zealand, 2nd edn. (Libro International, 2013), ebook edition.

18 “Mana Party Political Pamphlet,” http://mana.net.nz/wp-content/uploads/2011/10/Mana pamphlet_web.pdf (accessed 19 July, 2015).

19 “Fast Fire Leaders Question: God," NZ Herald, September 3, 2014, http://www.nzherald. co.nz/national/news/video.cfm?c_id=1503075\&gal_cid=1503075\&gallery_id=145226 (accessed 1 May, 2015).

20 See further: Keith Newman, Ratana: the Prophet (North Shore City: Raupo, 2009); Bronwyn Elsmore, “The Ratana Church” in Mana From Heaven, ebook edition. 
Ratana carried two books: the Bible and the Treaty." ${ }^{21}$ For the Ratana church, the Bible is very much to be found on the side of radical indigenous politics.

Yet, this alternative radical tradition can also manifest as an outright rejection of the Bible. Despite being viewed as the fulfillment of a prophecy in the eyes of Ratana church, Harawira himself comedically named "The Bible" as his favorite fictional book in a quiz of political party leaders. ${ }^{22}$ In fact, Harawira has explicitly expressed his view that the Bible is a tool of European colonial oppression. In a 2012 newspaper column, Harawira opined that "back in 1840, Māori owned the whole of Aotearoa, and although life wasn't exactly a bunch of roses, we had strong and vibrant societies dotted all round the country, until you guys [European settlers] introduced the gun, the Bible and the pox of course, and wreaked havoc and devastation like we'd never seen before." ${ }^{23}$ Harawira dismisses the Bible as a toxic text of terror, deemed guilty by its murky association with colonial history and economic exploitation.

As we will see, however, Winston Peters' use of the Bible is much more conventional and aligns closely with both the Cultural and Liberal Bibles. Despite his Māori heritage, the radical indigenous tradition of biblical interpretation is absent. Something of a savvy political operator, Peters' occasional references to the Bible function to build cachet amongst his various constituencies. This predominantly consists of an older voting demographic who might hold nostalgic sentiments for a bygone era of politics when the Bible was arguably afforded a more privileged standing in New Zealand society.

\section{Winston Peters: A Political Phenomenon?}

A recent unauthorized biography of Winston Peters brandishes the subtitle "the story of a political phenomenon" and begins with the following summation: "[l]ove him or loathe him (and there are few people to be found in the middle ground), Winston Peters has been a driving force, a Colossus, of New Zealand

21 Yvonne Tahana, “Hone Is Our Prophet, Ratana Parish Says,” NZ Herald, June 17, 2011, http:// www.nzherald.co.nz/nz/news/article.cfm?c_id=1\&objectid=10732715 (accessed 1 May, 2015).

22 Charlie Gates, “John Key likes... Johnny English?: Leaders Reveal Favourite Movies and Books,” The Dominion Post, November 23, 2011, http://www.stuff.co.nz/dominion-post/news/ politics/election-2011/6017292/John-Key-likes-Johnny-English (accessed 1 May, 2015).

23 Hone Harawira, "Paul Holmes, Māori Have Plenty to Protest,” NZ Herald, February 15, 2012, http://www.nzherald.co.nz/nz/news/article.cfm?c_id=1\&objectid=10785544 (accessed 1 May, 2015). 
politics for nigh on four decades." ${ }^{24}$ Although regularly construed as something of a maverick by the mainstream media, he has over his relatively long tenure held numerous offices of responsibility. First elected as a Member of Parliament (MP) for the National Party in 1978, Peters later founded his own political party, New Zealand First, which was subsequently elected to parliament in 1993 and continues to have a presence as a minor party. Currently in opposition, he previously served in government as the Deputy Prime Minister, Treasurer of New Zealand, Minister of Māori Affairs, and Minister of Foreign Affairs. In terms of recent global political trends, NZ First can be situated with nationalist forces on the political Right. A populist leader who often bemoans increased levels of immigration to New Zealand, Peters has also expressed opposition to neoliberal market reforms such as free trade, the increasing power given to offshore investors, and the outsourcing of manufacturing jobs.

Born in 1945 to a Scottish mother and Māori father, Peters grew up in Whananaki, a small rural town on the north east coast of the North Island. During a speech at his former primary school's 125th Jubilee in 2012, Peters remarked that the place "was a most unusual community, comprised of Māori and European, a significant number of which were members of the Exclusive Brethren Church." He joked that "most of us, whether Māori or European, had our noses pressed against the window because for this Church, the rest of us were all outsiders!"25

For the most part, however, Peters has not made a regular habit of sharing his personal views on religion. One exception is his occasional tongue-lashing against the so-called horrors of Islam. This appears to be linked to NZ First's broader stance on curtailing the flow of immigration. Peters implicitly harnesses the power of the Liberal Bible - the idea that the Bible undergirds Western democracy and its values - to solidify the impression of Muslim immigrants as "outsiders." For example, he has explicitly contrasted the "anti-Semitic, anti-Christian, and anti-gay (...) intolerance" of Islamic fundamentalism with New Zealand's own traditions, which are ostensibly not these things. In the wake of the 2005 London suicide bombings, Peters suggested that "[w]e cannot take our tradition of toleration for granted when we are importing fanatics for whom that tradition is alien" and moreover that "[i]n many parts of the world the Christian faith is

24 Ian Wishart, Winston: The Story of a Political Phenomenon (Auckland: Howling at the Moon, 2014), 1.

25 Winston Peters, “Whananaki Primary School - 125th Anniversary,” NZ First Party Website, October 12, 2012, http://nzfirst.org.nz/speech/whananaki-primary-school-125th-anniversary (accessed 1 May, 2015). 
under direct threat from radical Islam," ${ }^{26}$ thereby drawing an implicit connection between "Western" New Zealand society and a distinctly tolerant and liberal reading of Christianity.

While Peters' stance against both moderate and radical forms of Islam might stem from his populist partiality against immigration, such rhetoric also taps into a broadly entrenched view of the Bible itself as somehow underpinning the structures of Western civilization. Simply put: bourgeois democracy and liberal toleration are presumed to be an outworking of underlying biblical principles inherited from the Christian past. As Sherwood observes, "Western modernity has its own sacred sites - distinct notions of personhood, freedom, morality, democracy, rights, identity and respect/reverence for identities - which are often vaguely related back to Christianity and the Bible, as if these were the key enabling conditions for the discovery of these distinctly 'Western' goods." ${ }^{27}$ This is typically contrasted with the Qur'an, underpinning the supposedly anti-democratic and intolerant values of Islamic societies. Of course, as Sherwood argues, such views rest upon interpretations of what the Bible or Qur'an "really means" that are often anything but clear, stemming more from assumptions about these texts than through careful engagement.

Another example of Peters' foray into religion demonstrates how Peters uses the Bible to buttress existing political agendas. Again, this use does not stem from religious commitment, but rather from the presumed power of the Bible to bolster one's cultural credibility. Back in 2005 during a visit to Tauranga Boys' College, Peters spoke casually of his personal views on the Bible, including the small detail that he learned ancient Hebrew. During a question and answer session with the students, Peters, whose previous remarks on immigration have courted accusations of racism, made a potentially anti-Semitic joke about a Jewish man called Malachi who begged Jehovah to let him win the lottery so that he could pay for his sick daughter's operation. According to Peters "she couldn't wait for the hospital waiting lists - that's how you know it's about a New Zealand Jew." In a pre-emptive show of defense, however, Peters remarked: "Before you rush off thinking 'Ah, here comes one of his racist jokes' - which I never tell - I did Hebrew for my language at university." Declaring that "the Old Testament was my textbook," Peters explained in more detail:

26 Kevin Taylor and Claire Harvey, "Peters Warns of Muslim Serpents," NZ Herald, July 29, 2005, http://www.nzherald.co.nz/nz/news/article.cfm?c_id=1\&objectid=10338138 (accessed 1 May, 2015).

27 Sherwood, Biblical Blaspheming, 5. 
I was at University and I was doing law and I needed a classics subject, I looked around and went past this class and noticed up on the board were eight people signed up for ancient Hebrew, and all their names looked like they were Jewish. I thought, well, if I as a Gentile put my name up there, then I might get some pretty special treatment. They won't want me to fail. So I signed up to it, and luckily I passed, and it was one of the greatest things I ever did because it was fascinating. ${ }^{28}$

In a later interview with the $N Z$ Herald, Peters once again mentioned his knowledge of Hebrew. Justifying his choice of studying Hebrew over Māori, Peters asserted that:

All you have to understand about life is the works of Shakespeare and the Old Testament. Then you will understand what human nature is all about. Nothing has changed in all this time. [All other literature is] refinements of a work that has already been written. ${ }^{29}$

Peters' repeated fascination with Hebrew and the Old Testament in particular is intriguing given the importance of the Old Testament for Māori, as mentioned above. Yet, Peters' framing of his appreciation for the Old Testament appears to stem not from the indigenous Radical Bible tradition but rather from an acknowledgment of the supposed importance of the Cultural Bible for understanding Western society. The Old Testament, as well as certain "classics" like the works of Shakespeare, is seen to underpin universal truths about human nature. Shakespeare is a rather interesting counterpart in this respect given that his collected works can be seen to reflect a social situation marked by the collapse of feudalism and the onset of capitalist thinking. ${ }^{30}$ Peters' privileging of a distinctly Western canon to aid in the universal construction of modern bourgeois identity is typical of a much broader appeal to the Cultural Bible as an authority in contemporary political discourse.

\section{4 "Putting His Hand to the Plow": Winston Peters" Cultural Bible}

Having explored the various manifestations of the Bible in parliamentary politics, and introduced Winston Peters' occasional use of both the Cultural and Liberal

28 Claire Harvey, “Schoolboys Grill Peters," NZ Herald, August 22, 2005, http://www.nzherald. co.nz/nz/news/article.cfm?c_id=1\&objectid=10341640 (accessed 1 May, 2015).

29 Claire Trevett, “I Did It My Way,” NZ Herald, July 20, 2013, http://www.nzherald.co.nz/nz/ news/article.cfm?c_id=1\&objectid=10900416 (accessed 1 May, 2015).

30 See further: Paul N. Siegel, Shakespeare's English and Roman History Plays: A Marxist Approach (Rutherford, NJ: Fairleigh Dickinson University Press, 1986). 
Bibles, I now return to a deeper analysis of the event with which this article began, namely, Peters' explicit reference to Luke 9:62 on the eve of the Northland by-election. This unlikely appearance of the Bible raises several questions that demand our attention. This is because it was not, in fact, the first time Peters had quoted Luke 9:62 while speaking to the media. On at least two occasions, spaced ten years apart, Peters had cited the exact same verse to surprisingly different effect. As we will see, for Peters, the meaning of the text is highly malleable depending upon the (political) situation he applies it to. Even so, its usefulness as a cultural and rhetorical authority remains consistent.

The first time Peters is reported to have quoted this verse was for an interview with the NZ Herald in the lead up to the 2005 general election. Asked which of the main parties was his preferred coalition partner, and whether NZ First would be able to work alongside the Green party in a governing arrangement, Peters answered as follows:

We don't see that happening. Our predictions for the next election don't have that scenario happening (...) There's a famous verse in the Bible that goes like this: any man who sets his hand to the plough and then looks backwards is not fit for the Kingdom of Heaven. Politics is not heaven, but you get my point. . $^{31}$

The interviewer followed up by asking Peters about other potential coalition partners, leaving aside Peters' obscure biblical reference. During the 2015 Northland by-election, Peters once again returned to Luke 9:62. This time the quote was televised during the prime-time news. Look closely at the similarities between the surrounding text of this and the previous quote:

There's a famous verse in the Bible (...) now I know politics is not the same as spiritual things (...) but it says 'any man who having once set his hand to the plow and looks backwards is not fit for the kingdom of heaven'. You get the point don't you (...) we're not out to lose. ${ }^{32}$

Again, Peters suffixes his biblical citation with the claim that its "point" should be obvious, although this is arguably not the case. The grammatical use of the second person to ambiguously address both journalists and the public heightens its rhetorical effect. As Peters provides no exegesis of the text his intended

31 John Armstrong and Audrey Young, “Interview: Winston Peters, NZ First Party Leader," NZ Herald, July 30, 2005, http://www.nzherald.co.nz/nz/news/article.cfm?c_id=1\&objectid=10338212 (accessed 1 May, 2015).

32 “John Key Has More Promises for Northland,” One News, March 27, 2015, http://tvnz.co.nz/ national-news/john-key-has-more-promises-northland-video-6271539 (accessed 1 May, 2015). 
meaning or application remains somewhat obscure. Within its broader literary context in the Gospel of Luke, the verse occurs during Jesus' journey to Jerusalem and is one of three sayings addressed to would-be followers (Luke 9:57-62). Joseph Fitzmyer suggests that "[p]lowing for the Kingdom means sacrifice; it can tolerate no distractions. Following Jesus means devotion to kingdom-work and transcends even ordinary family affection." 33 The fact that the original text is itself somewhat vague as to its application beyond the immediate vicinity of agricultural labor provides Peters with the perfect opportunity to re-contextualize it. One might deduce that Peters is claiming his own determination will pay off, echoing the aspirational capitalist myth that hard work reaps its appropriate reward. While Jesus is speaking of the determination of Christian discipleship (of following Jesus and striving for the kingdom of God), Peters re-appropriates the text to make it about his own self-determination and political ambitions.

Peters also prefaces both these citations with the maxim, "[t]here's a famous verse in the Bible (...)". Even if his audience is unfamiliar with the biblical verse he cites, they no doubt understand what a Bible is and the cultural and religious power it purportedly represents. Accordingly, the maxim functions as a dog-whistle to his various constituencies. On the one hand, the positive framing of the Bible should appeal to Christians who regard it as their sacred text. On the other hand, Peters exhibits an aptitude for the Western cultural canon - his ability to recite biblical passages demonstrates an awareness and literacy that should allure those who recognize - even implicitly - the Bible as a foundational document in Western culture. In both cases, the content of the Bible is not as important as the fact that he is quoting from it. This is a perfect demonstration of the Bible-as-icon and/or the Cultural Bible in contemporary political discourse.

Another curious aspect worth teasing out concerns Peters' modification of the verse he quotes. The New Revised Standard Version renders Luke 9:62 as follows: "Jesus said to him, 'No one who puts a hand to the plow and looks back is fit for the Kingdom of God'." On both occasions, however, Peters departs from any known English translation (although the King James Version is his likely source given the use of masculine pronouns). The simple explanation is that Peters has memorized the verse incorrectly. Be that as it may, the variation at the end of the quote is potentially revealing. Whereas all major English translations contain "kingdom of God," Peters' version adopts the more Matthean-sounding "kingdom of heaven.” While this saying of Jesus is absent from Matthew's gospel, and can

33 Joseph A. Fitzmyer, The Gospel According to Luke I-IX, The Anchor Bible 28 (New York: Doubleday, 1982), 834. 
only be from Luke, ${ }^{34}$ Peters' redaction might implement a similar circumlocutory logic as does the Matthean text. Indeed, in contrast to the other canonical gospels which speak of the "kingdom of God," the Gospel of Matthew uniquely speaks of the "kingdom of heaven," with "heaven" functioning as a periphrasis for God, perhaps under rabbinic influence of avoiding the divine name. ${ }^{35}$ Intriguingly, the redaction of "God" to "heaven" allows Peters to utilize the biblical passage without directly invoking God. His subtle alteration of the text shows a similar reverence, although here directed towards the implicit etiquette of talking religion in New Zealand parliamentary politics: above all else, do not invoke God.

Peters seems to be aware of this implied code of conduct given his respective asides which function to excuse the fact that he is quoting from the Bible in the first place. In the 2005 quote, Peters notes that "[p]olitics is not heaven." In the 2015 quote, Peters cautions that "politics is not the same as spiritual things." These asides distance Peters from the biblical text that he subsequently cites. The idea is that the audience should not take his use of the Bible too seriously. Even so, it is tacitly acknowledged that the Bible nonetheless functions as a repository of universal wisdom. This might lead us to ask, given the delicacies with which one must skirt around the sensitive topic of religion in contemporary political discourse, why would a politician bother to reference the Bible at all?

\section{Concluding Remarks: The Cultural Bible, Secular Politics, and the Horizon of Capital}

Why does the Bible creep into the most unlikely of places? The meaning of Luke 9:62 appears to have no direct significance for either Peters or for the seemingly arbitrary political situations he applies it to. The most obvious reason for why a politician would quote the Bible is because they are a dedicated Christian and so the Bible plays a central role in their life and political views. In other words, the convergence between religion and politics is one driven largely by a politician's personal religious convictions. This is a primary reason for the Bible's more frequent appearance in US political discourse. However, it appears not to be the case

34 The first two sayings in 9:57-62 are derived from "Q" being also found in Matthew 8:19-22. However, the third is derived from "L," although it could also be the product of Lucan composition, “ added in either case to make a threesome.” Fitzmyer, Luke I-IX, 833.

35 W. D. Davies and D. C. Allison, Matthew 1-7, International Critical Commentary (London: T\&T Clark, 1988), 390. 
for Peters, whose political ambitions are not undergirded by any noticeable faith commitments.

Another reason why a politician might use the Bible is to gain, or at least not to lose, the support of different voting constituencies. There could be a significant enough base of the population who appreciates references and allusions to the Bible, although these need to be utilized in a way that does not alienate those who are less impressed. Peters' voting demographic largely consists of older Pākehā who arguably find the Cultural and Liberal Bibles palatable given the Bible's once more prominent cultural and religious status in New Zealand society (even though its prominence has historically waxed and waned). Keeping steadfast to past traditions is a frequent rhetorical trope utilized by NZ First's wider political platform. Appeals to the Cultural Bible form an integral part of this trope. It is also worth noting that the increase of irreligion, or religious indifference, within New Zealand society is statistically predominant among younger New Zealanders who, broadly speaking, fall outside of the purview of NZ First's core demographic. ${ }^{36}$ As such, those who identify as Christian are more likely to be older and might respond more favorably to Peters' use of the Bible. Nevertheless, Peters and his audience seem aware that the arbitrary albeit "sacred" distinction between religious and political matters is implicitly upheld within the domain of New Zealand political discourse. Accordingly, Peters qualifies his use of the Bible with a coded disclaimer; his recitation functions purely as a rhetorical gesture based on its perceived cultural authority. ${ }^{37}$

Although the Bible occasionally resurfaces in New Zealand political discourse, it is unlikely to have much influence on the direction of political discussion overall. As noted above, the Bible can be used to support movements on both the political Left and the Right. Even so, Peters' Bible is allied to an older style of capitalism positioned against certain tenets of neoliberal ideology. The Bible is purportedly on the side of protecting national economic sovereignty from market globalization, promoting the liberal value of tolerance, and upholding the old capitalist myth that hard work and determination will reap its fair reward.

36 "Census QuickStats about Culture and Identity."

37 While fewer New Zealanders regard the Bible as a religious authority its importance as a cultural icon remains prevalent. Indeed, it would not have mattered what verse Peters quoted, the very fact that he references the Bible and prefaces his quote with the deliberate "[t]here's a famous verse in the Bible" indicates that Peters believes the combination of words that follow will have some kind of added prestige and authenticity. The content of the text is not as important as the fact that the Bible itself is the object being quoted. Luke 9:62 simply forms part of Peters' rhetorical arsenal of memorized quotes that he can recall at any given moment. 
If analyzed with respect to the economic base upon which the Cultural Bible is ultimately dependent, the Bible's presumed authority in Western society can and should be situated within the realm of capitalist relations: it functions as part of the ideological superstructure that upholds current configurations of class and economy. Indeed, the often-understated connection between liberal thought, bourgeois parliamentary democracy, and the rise of the capitalist mode of production remains instructive here. As we have seen, the Cultural and Liberal Bibles in particular are effective props of bourgeois ideology. They function as icons of vested cultural authority - attributes gained largely through historical accident - which entrench some of the more recent assumptions of liberal and capitalist thought by "discovering" their precedence in ancient and seemingly mystical texts. Such cultural and ideological artifacts are required in order to transform capitalism's limited and particular social formation into a supposedly timeless and universal narrative of human development and progress.

\section{Works Cited}

Armstrong, John, and Audrey Young. 2005. "Interview: Winston Peters, NZ First Party Leader." NZ Herald, July 30. Accessed May 1. 2015. http://www.nzherald.co.nz/nz/news/article. cfm?c_id=1\&objectid=10338212.

Bhabha, Homi K. 1994. The Location of Culture. London: Routledge.

Boer, Roland. 2010. "Introduction." In Secularism and Biblical Studies, edited by Roland Boer, 1-12. BibleWorld. London: Equinox.

"Census QuickStats about Culture and Identity." 2014. Statistics New Zealand: Tatauranga Aotearoa, April 15. Accessed May 1, 2015. http://www.stats.govt.nz/Census/2013-census/ profile-and-summary-reports/quickstats-culture-identity/religion.aspx.

Crossley, James G. 2014. Harnessing Chaos: The Bible in English Political Discourse Since 1968. Scriptural Traces. London: Bloomsbury.

Crossley, James G. 2012. Jesus in an Age of Neoliberalism: Quests, Scholarship, and Ideology. Sheffield: Equinox.

Davidson, Allan K. 1996. "The Interaction of Missionary and Colonial Christianity in Nineteenth Century New Zealand." Studies in World Christianity 2: 145-166.

Davies, W. D., and D. C. Allison. 1988. Matthew 1-7. International Critical Commentary. London: T\&T Clark.

Elsmore, Bronwyn. 2011. Like Them That Dream: The Mãori and the Old Testament. 3rd edn. Auckland: Libro International.

Elsmore, Bronwyn. 2013. Mana From Heaven: A Century of Maori Prophets in New Zealand. 2nd edn. Libro International, ebook edition.

“Fast Fire Leaders Question: God." 2014. NZ Herald, September 3. Accessed May 1, 2015. http:// www.nzherald.co.nz/national/news/video.cfm?c_id=1503075\&gal_cid=1503075\&gallery_ id $=145226$. 
Fitzmyer, Joseph A. 1982. The Gospel According to Luke I-IX. The Anchor Bible 28. New York: Doubleday.

Gates, Charlie. 2011. “John Key likes...Johnny English?: Leaders Reveal Favourite Movies and Books.” The Dominion Post. November 23. Accessed May 1, 2015. http://www.stuff.co.nz/ dominion-post/news/politics/election-2011/6017292/John-Key-likes-Johnny-English.

Gunn, David M. 1998. “Colonialism and the Vagaries of Scripture: Te Kooti in Canaan (A Story of Bible and Dispossession in Aotearoa/New Zealand)." In God in the Fray, edited by Tod Linafelt and Timothy K. Beal, 127-42. Minneapolis: Fortress.

Harawira, Hone. 2012. "Paul Holmes, Māori Have Plenty to Protest.” NZ Herald, February

15. Accessed May 1, 2015. http://www.nzherald.co.nz/nz/news/article.cfm?c_ id=1\&objectid=10785544.

Harvey, Claire. 2005a. “Schoolboys Grill Peters.” NZ Herald, August 22. Accessed May 1, 2015. http://www.nzherald.co.nz/nz/news/article.cfm?c_id=1\&objectid=10341640.

Harvey, David. 2005b. A Brief History of Neoliberalism. Oxford: Oxford University Press. Huie-Jolly, Mary. 2002. “Māori ‘Jews' and a Resistant Reading of John 5.10-47.” In John and Postcolonialism: Travel, Space and Power, edited by Musa W. Dube and Jeffrey L. Staley, 94-110. London: Sheffield Academic.

“John Key Has More Promises for Northland.” 2015. One News, March 27. Accessed May 1, 2015. http://tvnz.co.nz/national-news/john-key-has-more-promises-northland-video-6271539.

Losurdo, Domenico. 2011. Liberalism: A Counter-History, trans. Gregory Elliott. London: Verso. Maddox, Marion. 2005. God Under Howard: The Rise of the Religious Right in Australian Politics. Crows Nest, NSW: Allen \& Unwin.

“Mana Party Political Pamphlet.” 2014. Accessed August 21, 2014. http://mana.net.nz/ wp-content/uploads/2011/10/Mana_pamphlet_web.pdf.

Mckinlay, Judith E. 2014. Troubling Women and Land: Reading Biblical Texts in Aotearoa New Zealand. Bible in the Modern World 59. Sheffield: Sheffield Phoenix.

McKinlay, Judith E. 2012. "Braiding the Traditions in Aotearoa/New Zealand." In The Future of the Biblical Past: Envisioning Biblical Studies on a Global Key, edited by Roland Boer and Fernando F. Segovia, 207-22. Atlanta: Society of Biblical Literature (SBL), 2012.

Myles, Robert J. 2014. The Homeless Jesus in the Gospel of Matthew. Sheffield: Sheffield Phoenix.

Newman, Keith. 2009. Ratana: The Prophet. North Shore City: Raupo.

Peters, Winston. 2012. “Whananaki Primary School - 125th Anniversary.” NZ First Party Website, October 12. Accessed May 1, 2015. http://nzfirst.org.nz/speech/whananaki-primaryschool-125th-anniversary.

Runions, Erin. 2014. The Babylon Complex: Theopolitical Fantasies of War, Sex, and Sovereignty. New York: Fordham University Press.

Siegel, Paul N. 1986. Shakespeare's English and Roman History Plays: A Marxist Approach. Rutherford, NJ: Fairleigh Dickinson University Press.

Sherwood, Yvonne. 2012. Biblical Blaspheming: Trials of the Sacred for a Secular Age. Cambridge: Cambridge University Press (CUP).

Tahana, Yvonne. 2011. “Hone Is Our Prophet, Ratana Parish Says.” NZ Herald, June 17. Accessed May 1, 2015. http://www.nzherald.co.nz/nz/news/article.cfm?c_ id=1\&objectid=10732715.

Taylor, Kevin, and Claire Harvey. 2005. "Peters Warns of Muslim Serpents.” NZ Herald, July 29. Accessed May 1, 2015. http://www.nzherald.co.nz/nz/news/article.cfm?c id=1\&objectid=10338138. 
Trevett, Claire. 2013. “I Did It My Way.” NZ Herald, July 20. Accessed May 1, 2015. http://www. nzherald.co.nz/nz/news/article.cfm?c_id=1\&objectid=10900416.

Tunnah, Hannah. 2003. "Art of Compromise at Coalition Party Conference." NZ Herald, March 11. Accessed May 1, 2015. http://www.nzherald.co.nz/nz/news/article.cfm?c_ id=1\&objectid=3532099.

Wishart, Ian. 2014. Winston: The Story of a Political Phenomenon. Auckland: Howling at the Moon. 